\title{
Adara, A Plum Rootstock for Cherries and Other Stone Fruit Species
}

\author{
M.A. Moreno, M.C. Tabuenca, and R. Cambra \\ Departamento de Pomología, Estación Experimental de Aula Dei \\ (Consejo Superior de Investigaciones Científicas), Apartado 202, 50080 \\ Zaragoza, Spain
}

Additional index words. Prunus cerasifera, Prunus avium, propagation, compatibility

Adara is a plum rootstock developed at the Estación Experimental de Aula Dei,Zaragoza, Spain, for use as a rootstock for sweet cherry (Prunus avium L.) and sour cherry (P. cerasus L.). A high proportion of peach and nectarine $[P$. persica (L.) Batsch] cultivars, as well as Japanese plum ( $P$. salicina Lindl) cultivars, have shown a good response, although the interest in Adara for these species may be more limited.

Adara was selected from an open-pollinated population of Myrobalan (P. cerasifera Ehrh.), although its genetic identity has not been defined.

Scions of cherry grafted on Adara grow well; most cherry cultivars have shown good graft-compatibility, although some cultivars are incompatible (Table 1). Further tests are needed to explore the full range of compatible cultivars as has been demonstrated with other cherry rootstocks (Perry, 1987). Trees are more vigorous than on Colt $(P$. avium $\times P$. pseudocerasus) or St. Lucie 64 ( $P$. mahaleb L.), and yield efficiency of cultivars on Adara is higher than that on either of these other rootstocks (Table 2). Furthermore, Adara appears to be more efficient in the uptake of some mineral elements; higher concentrations of $\mathrm{N}$, $\mathrm{K}$, and $\mathrm{Mn}$ have been found in leaves of ' $\mathrm{Van}$ ' cherry scion compared to 'Van' on St. Lucie 64 or Colt (M.A.M., unpublished).

Adara is easily propagated by hardwood cuttings. About $90 \%$ of hardwood cuttings treated with indole-3-butyric acid (indolebutyric acid) at $500 \mathrm{mg} \cdot \mathrm{liter}^{-1}$ rooted (Moreno, 1989).

Received for publication $27 \mathrm{Feb}$. 1995. Accepted for publication 20 June 1995. Financial support was provided by Comisión Asesora de Investigación Científica y Técnica and Comisión Interministerial de Ciencia y Tecnología. Consejo Asesor de Investigación de la Diputación General de Aragón and Consejo Superior de Investigaciones Científicas supported M.A.M. We thank A. Blanco and A.M. Casas for critical reading and translation of this manuscript. The cost of publishing this paper was defrayed in part by the payment of page charges. Under postal regulations, this paper therefore must be hereby marked advertisement solely to indicate this fact.
All nursery and orchard trials were performed on heavy clay and calcareous soils, with alkaline $\mathrm{pH}$ (8 to 9) and high total (30\% to $35 \%$ ) and active (10\% to $11 \%$ ) lime. Adara adapts well to these soils, being resistant to $\mathrm{Fe}$ chlorosis and root asphyxia. Adara appears to be a promising rootstock for many cherry cultivars grown in heavy and poorly drained soils or under irrigation where other rootstocks fail to survive (Table 3 ).

\section{Origin}

Adara was selected from an open-pollinated population of Myrobalan. Selection work was performed at Estación Experimental de Aula Dei. The clone initially was tested as plum 2977 AD and was released because it had good rooting ability (Moreno, 1989); it is highly resistant to root asphyxia and associated diseases and has a higher yield efficiency than other cherry rootstocks. In addition, Adara shows a lower tendency to sucker compared to St. Lucie, a rootstock widely used for cherries in calcareous and well-drained soils. Soil adaptability problems experienced with St. Lucie or other $P$. mahaleb stocks, when grown under irrigation and waterlogging conditions, stimulated the clonal selection of Adara.

\section{Compatibility}

Adara has shown good graft compatibility with 44 sweet and some sour cherry cultivars (Table 1) when tested in nursery or in orchard trials (Moreno and Tabuenca, 1991; Tabuenca and Moreno, 1988). Nevertheless, a few cultivars of sour and sweet cherry have shown graft incompatibility (Table 1), according to the criteria of Herrero (1951) and Mosse (1962). Peaches and nectarines grafted on Adara display different compatibilities depending on the cultivar, but a high proportion appears to be compatible with this rootstock (Table 4). Adara also is graft-compatible with Japanese plum, although the range of cultivars tested is not extensive (Table 5). This rootstock also has been tested with apricot (P. armeniaca L.) and almond [P. dulcis (Mill.) D.A. Webb]; the compatibility depends on the cultivar (Table 5) (Moreno and Tabuenca, 1991; Tabuenca and Moreno, 1988). 'Moniqui' apricot and 'Desmayo' almond have shown graft-incompatibility on Adara, although to a lesser degree than when they were on Myrobalan B.
Table 1 . Compatibility rating for cherry scion cultivars on Adara rootstock.

\begin{tabular}{|c|c|c|}
\hline Cultivar & $\begin{array}{l}\text { No. } \\
\text { trees }\end{array}$ & Compatibility \\
\hline \multicolumn{3}{|l|}{ Prunus avium } \\
\hline Ambrunes & 35 & $\mathrm{C}$ \\
\hline Bing & 10 & $\mathrm{C}$ \\
\hline Blanca de Provenza & 20 & $\mathrm{C}$ \\
\hline Burlat & 50 & $\mathrm{C}$ \\
\hline Burlat C1 & 29 & $\mathrm{C}$ \\
\hline Colalarga & 19 & $\mathrm{C}$ \\
\hline Compact Stella & 10 & $\mathrm{C}$ \\
\hline Coeur de Pigeon & 10 & $\mathrm{C}$ \\
\hline Corum & 5 & $\mathrm{C}$ \\
\hline Cristobalina & 10 & $\mathrm{C}$ \\
\hline Cherovina & 10 & $\mathrm{C}$ \\
\hline Chinook & 10 & $\mathrm{C}$ \\
\hline Ebony & 10 & $\mathrm{C}$ \\
\hline Garrafal de Lérida & 10 & $\mathrm{C}$ \\
\hline Gorda Negra Dura & 20 & $\mathrm{C}$ \\
\hline Guillaume & 10 & $\mathrm{C}$ \\
\hline Hedelfinger & 20 & $\mathrm{C}$ \\
\hline Jaboulay & 10 & $\mathrm{C}$ \\
\hline Jarandilla & 10 & $\mathrm{C}$ \\
\hline Lapins & 30 & $\mathrm{C}$ \\
\hline Moreau & 50 & $\mathrm{C}$ \\
\hline Picota & 15 & $\mathrm{C}$ \\
\hline Precoce Bernhard & 28 & $\mathrm{C}$ \\
\hline Rainier & 5 & $\mathrm{C}$ \\
\hline Ramón Oliva & 10 & $\mathrm{C}$ \\
\hline Ripolla & 110 & $\mathrm{C}$ \\
\hline Sam & 22 & $\mathrm{C}$ \\
\hline Sparkle & 5 & $\mathrm{C}$ \\
\hline Star & 20 & $\mathrm{C}$ \\
\hline Stark Hardy Giant & 50 & $\mathrm{C}$ \\
\hline Sue & 5 & $\mathrm{C}$ \\
\hline Sunburst & 30 & $\mathrm{C}$ \\
\hline Summit & 15 & $\mathrm{C}$ \\
\hline Tardif de Vignola & 110 & $\mathrm{C}$ \\
\hline Ulster & 10 & $\mathrm{C}$ \\
\hline Valera & 20 & $\mathrm{C}$ \\
\hline Van & 125 & $\mathrm{C}$ \\
\hline Vega & 15 & $\mathrm{C}$ \\
\hline Velvet & 30 & $\mathrm{C}$ \\
\hline Vic & 10 & $\mathrm{C}$ \\
\hline Villareta & 10 & $\mathrm{C}$ \\
\hline Viscount & 25 & $\mathrm{C}$ \\
\hline Vogue & 29 & $\mathrm{C}$ \\
\hline Wño (Daiber) & 10 & $\mathrm{C}$ \\
\hline Gil Peck & 40 & A \\
\hline Larian & 19 & A \\
\hline Nero II & 28 & A \\
\hline Spalding & 30 & A \\
\hline Napoleon & 44 & I \\
\hline Taleguera Brillante & 40 & I \\
\hline \multicolumn{3}{|l|}{ Prunus cerasus } \\
\hline Ferracida & 10 & $\mathrm{C}$ \\
\hline Negra de Serra & 20 & $\mathrm{C}$ \\
\hline Reina Hortensia & 10 & $\mathrm{C}$ \\
\hline Temprana de Sot & 18 & $\mathrm{C}$ \\
\hline Montmorency & 20 & I \\
\hline Montmorency Sauvigny & 10 & I \\
\hline \multicolumn{3}{|l|}{ Prunus serrulata } \\
\hline Shirofugen & 20 & $\mathrm{C}$ \\
\hline
\end{tabular}

${ }^{\mathrm{Z}} \mathrm{C}=$ compatible, normal trees, continuous bark, and wood in the union; $\mathrm{A}=$ abnormal scion behavior, leaf yellowing, reduction in vigor; $\mathrm{I}=$ incompatible, cambial, or vascular discontinuity in the union. The cases of abnormal scion behavior and discontinuity in the union already were shown during the first 3 years following grafting. Nevertheless, tests were continued and macroscopical examination of the unions also were made when trees were 5 years old. Some compatible cultivars have been in commercial orchards for 12 years. 


\section{Description}

Adara is similar to 'Myrobalan', the latter also known as cherry plum for its comparative similarity of fruit to cherry (Ramming and Cociu, 1989; Tukey, 1964). Unworked maiden trees of Adara have a vigor similar to ' $\mathrm{My}$ robalan B'. Their growth habit is semiupright, with branches spreading more than those of 'Myrobalan B'.

One-year-old shoots are purplish red-green in spring and summer and brown and purplish red in winter. Internodes are short-medium in length, and leaves are those of a fast-growing plum type, medium in size, and green with wavy dentate margins. Mean length : width ratio of the leaf blade is $1.41 \pm 0.06$, slightly lower than that of 'Myrobalan B' (1.86 \pm 0.03). Leaf petioles are channeled and a pinkpurple color. At the beginning of growth, leaves present small stipules. Leaf fall is late in the autumn.

Flower budbreak on Adara occurs earlier in spring than on $P$. domestica L. or P. insititia L. Bullace plums and at the same time as 'Myrobalan B' or 'Myrobalan GF 31'. Adara has small white flowers with one pistil. The stigma position is at the same level as the anthers or slightly lower. The anthers are yellow just before dehiscence. Fruit are rounded, symmetric, and similar in size to those of 'Myrobalan B'. The skin is yellow, with a little skin bloom. Flesh is yellow, juicy, and, in our judgement, sweet and pleasant to eat. The stone is semi-adherent and light pink, with round-elliptical and asymmetric shape in lateral view (length : breadth ratio $=1.34 \pm 0.07$ ) and semi-globular in front view (length: width

Table 2. Rootstock effects on trunk cross-sectional area (TCSA) and yield efficiency of 'Van' cherry cultivar for the first 9 years in the orchard.

\begin{tabular}{lccc}
\hline \hline & $\begin{array}{c}\text { Cumulative } \\
\text { TCSA } \\
\left(\mathrm{cm}^{2}\right)\end{array}$ & $\begin{array}{c}\text { Yield } \\
(\mathrm{kg} / \mathrm{tree})\end{array}$ & $\begin{array}{c}\text { Yield } \\
\text { efficiency } \\
\left(\mathrm{kg} / \mathrm{cm}^{2}\right. \\
\text { TCSA })\end{array}$ \\
\hline Adara & $387 \mathrm{c}^{2}$ & $240 \mathrm{c}$ & $0.62 \mathrm{c}$ \\
Colt & $158 \mathrm{a}$ & $65 \mathrm{a}$ & $0.41 \mathrm{a}$ \\
St. Lucie 64 & $294 \mathrm{~b}$ & $150 \mathrm{~b}$ & $0.51 \mathrm{~b}$ \\
\hline
\end{tabular}

${ }^{2}$ Mean separation within columns by Duncan's multiple range test at $P \leq 0.05$.

Table 3. Percentage of dead trees for the first 10 years of 'Van' and 'Tardif de Vignola' cherry grafted on the various rootstocks when grown in an orchard with a heavy clay soil and under irrigation conditions $(n=16)$.

\begin{tabular}{lcc}
\hline & \multicolumn{2}{c}{ Dead trees (\%) } \\
\cline { 2 - 3 } & \multicolumn{2}{c}{ Scion cultivar } \\
\cline { 2 - 3 } Rootstock & Van & Tardif de Vignola \\
\hline Adara & 0 & 0 \\
Colt & 6 & 19 \\
St. Lucie 64 & 13 & 38 \\
\hline
\end{tabular}

Table 4. Compatibility rating for peach and nectarine scion cultivars on Adara rootstock.

\begin{tabular}{|c|c|c|c|c|c|}
\hline \multirow[b]{2}{*}{ Cultivar } & \multirow{2}{*}{$\begin{array}{c}\text { No. } \\
\text { trees }\end{array}$} & \multirow{3}{*}{ Compatibility $^{\mathrm{z}}$} & Stock. & & \\
\hline & & & \multirow[b]{2}{*}{ Cultivar } & \multirow{2}{*}{$\begin{array}{l}\text { No. } \\
\text { trees }\end{array}$} & \multirow[b]{2}{*}{ Compatibility $^{2}$} \\
\hline Peaches & & & & & \\
\hline Alejandro Dumas & 10 & $\mathrm{C}$ & Japanese plums & & \\
\hline Amarillo de Calanda & 20 & $\mathrm{C}$ & Delbarazur & 32 & $\mathrm{C}$ \\
\hline Amarillo de Gallur & 20 & $\mathrm{C}$ & Friar & 30 & $\mathrm{C}$ \\
\hline Borracho de Jarque & 10 & $\mathrm{C}$ & Golden Japan & 30 & $\mathrm{C}$ \\
\hline Calanda San Miguel & 20 & $\mathrm{C}$ & Santa Rosa & 20 & $\mathrm{C}$ \\
\hline Catherina & 50 & $\mathrm{C}$ & European plums & & \\
\hline Cofrentes & 10 & $\mathrm{C}$ & President & 10 & $\mathrm{C}$ \\
\hline Corona & 20 & $\mathrm{C}$ & Reine Claude Tardif & 10 & $\mathrm{C}$ \\
\hline Dixon & 20 & $\mathrm{C}$ & Reine Claude de Bavay & 10 & $\mathrm{C}$ \\
\hline Halford & 10 & $\mathrm{C}$ & Apricots & & \\
\hline Klamt & 10 & $\mathrm{C}$ & Paviot & 15 & $\mathrm{C}$ \\
\hline Maluenda & 20 & $\mathrm{C}$ & Moniqui & 80 & $\mathrm{I}$ \\
\hline Maruja Porvenir & 10 & $\mathrm{C}$ & Almonds & & \\
\hline Miraflores & 20 & $\mathrm{C}$ & Marcona & 10 & $\mathrm{C}$ \\
\hline Paloro A & 10 & $\mathrm{C}$ & Desmayo & 10 & $\mathrm{I}$ \\
\hline Paloro B & 10 & $\mathrm{C}$ & ${ }^{2} \mathrm{C}=$ Compatible, normal tr & es, con & inuous bark and \\
\hline Rojo del Rito & 10 & $\mathrm{C}$ & wood in the union; $I=1$ & alized & incompatibility, \\
\hline San Lorenzo & 20 & $\mathrm{C}$ & cambial or vascular discon & & the union. Data \\
\hline Stanford & 20 & $\mathrm{C}$ & from Moreno and Tabuen & $(1991$ & \\
\hline Sudanell 2 & 20 & $\mathrm{C}$ & & & \\
\hline
\end{tabular}

ratio $=2.07 \pm 0.09)$. The stone is small, similar to that of 'Myrobalan GF 31' and slightly larger than that of 'Myrobalan B'.

\section{Availability}

Adara registration is in progress. Small amounts of rooted cuttings or budwood can be obtained from the Estación Experimental de Aula Dei. Adara is free of all known viruses (Moreno, 1989; Moreno and Tabuenca, 1991).

\section{Literature Cited}

Herrero, J. 1951. Studies of compatible and incompatible graft combinations with special reference to hardy fruit trees. J. Hort. Sci. 26:186-237.

Moreno, M.A. 1989. Características descriptivas del patrón ciruelo Adara. Anales de la Estación Experimental de Aula Dei 19:293-300.

Moreno, M.A. and M.C. Tabuenca. 1991. El patrón ciruelo 'Adara': Su comportamiento con variedades de cerezo y de otras especies frutales. Información Técnica Económica Agraria 87V(1):25-35.

Mosse, B. 1962. Graft-incompatibility in fruit trees with special reference to its underlying causes. Technical Communication no. 28, Commonwealth Agricultural Bureaux, Farnham Royal, Bucks, U.K.

Perry, R.L. 1987. Cherry rootstocks, p. 217-264. In: R.C. Rom and R.F. Carlson (ed.). Rootstocks for fruit crops. Wiley, New York.

Ramming, D.W. and V. Cociu. 1989. Plums (Prunus). Acta Hort. 290:235-287.

Tabuenca, M.C. and M.A. Moreno. 1988 Incompatibilidad entre patrón e injerto. Comportamiento de un ciruelo como patrón de distintas especies frutales. Anales de la Estación Experimental de Aula Dei 19:251-263.

Tukey, H.B.1964. Dwarfed fruit trees. Cornell Univ. Press, Ithaca, New York. 